\title{
CHARACTERISTICS OF OUTDOOR THERMAL COMFORT INDEX (OCTI) AT MANDEH TOURISM SITE
}

\author{
*Ratna Wilis ${ }^{12}$, Sugeng Nugroho ${ }^{3}$, Eri Barlian² and Nurhasan Syah² \\ ${ }^{1}$ Doctoral Program of Environmental Sciences, Postgraduate - Padang State University, Indonesia \\ ${ }^{2}$ Department of Geography, Faculty of Social Sciences - Padang State University, Indonesia \\ ${ }^{3}$ Padang Pariaman Climatological Station, BMKG, Indonesia
}

*Corresponding Author, Received: 20 Dec. 2019, Revised: 25 Feb. 2020, Accepted: 23 April 2020

\begin{abstract}
Tourism is one of the fast growing business sectors today. Outdoor Thermal Comfort Index (OCTI) is useful information for tourists. The study was conducted at the Mandeh tourist area. OCTI is calculated based on climate data for the 1979-2015 period. RayMan software is used to calculate OCTI expressed in Physiological Equivalent Temperature (PET). Calculation results show that the characteristics of the annual OCTI in Mandeh are dominated by the Slightly Warm category (98\%) and Comfortable (2\%). Characteristics of daily OCTI: morning (00 utc) and evening (18 utc) are dominated by the Comfortable (90\%) and Warm (10\%) categories. During the day (06 utc) the Slightly warm category (60\%) and Comfortable (90\%). Towards night (12 utc), a more diverse OCTI category emerged: Comfortable (7\%), Slightly Warm (31\%), Warm (41\%), Hot (20\%), and Very Hot (1\%). The unique characteristics of OCTI at this time are thought to be because the location of the data sample taken is in a bay, where the PET value is not only influenced by surface air temperature at the location but also the presence of ocean-land interactions which causes the PET value to be unique at that time. During 1979-2015, there was a shift in PET, where the trend in the Slightly Warm category continued to increase and the Comfortable category declined. For tourists, the characteristics of OCTI can be used as a guide when the right time for a vacation and for tourism businesses and local governments as a guide for tourism development in Mandeh.
\end{abstract}

Keywords: Tourism, Outdoor thermal comfort index, PET, Mandeh

\section{INTRODUCTION}

Beautiful natural scenery, such as topography, natural landscape, vegetation, fauna and geographic location are factors that influence the decision for tourists in choosing the location to be visited. Tourism activities that promote nature and outdoor activities are greatly influenced by weather and climate factors. For tourists the weather and climate factors will influence the form of activities and activities outside the room and even influence decisions in terms of property that will be worn during the tour, for example the model and color of the clothes. The influence of weather and climate factors not only for tourists but also for tourism businesses, such as in planning and designing tourism resorts, recreation areas, arranging visit schedules, and so forth. Thus, tourists, tour operators, travel agents, tourism planners and stakeholders need to know the influence of weather and climate factors on tourism activities in several locations that become tourist destinations [1].

Beach tourism is one of the global tourism market segments, which is strongly influenced by the thermal conditions of the coastal region. According to the results of study at beach tourists generally prefer warm conditions when they move around the coast [2]. Meanwhile, tourists in urban areas, such as city parks and squares, prefer if the thermal conditions in the comfortable category when they are outdoors [3].

In tropical tourism destinations that tend to be humid, the air temperature and especially the relatively high air humidity are the main causes of the situation being thermally uncomfortable for humans. In addition to climatic factors, a person's level of thermal comfort is also influenced by other factors, namely: the type of clothing worn, the level of activity, body dimensions and the level of skin wetness (sweat) of that person [4]. Weather and climate factors or generally referred to as the atmosphere that most influences on tourism activities is the factor of heat (thermal), because this factor can affect the comfort level of someone in each of their activities, especially for outdoor activities. Thermal comfort is a process that involves physical and psychological processes. So that thermal comfort is the condition of the mind of someone who expresses his satisfaction with his thermal environment. With the understanding of thermal comfort as a thought condition that expresses a person's level of satisfaction with the thermal environment, it means that thermal comfort will involve three aspects including physical, biological and psychological, with the 
understanding of thermal comfort based on psychological approaches is the most complete meaning [5]

One method that can be used to assess a person's comfort level due to thermal impacts is Physiological Equivalent Temperature (PET), which is included in the field of biometeorology / bioclimatology studies. PET index values have 9 levels of thermal perception from very cold (PET $\left.<4^{\mathrm{O}} \mathrm{C}\right)$ to very hot $\left(\mathrm{PET}>41^{\mathrm{O}} \mathrm{C}\right)$. PET is a model used to express the level of thermal comfort based on the energy balance of the human body. PET is expressed in units of degrees Celsius $\left({ }^{\circ} \mathrm{C}\right)$ so that the results will be easier to understand compared to results from other thermal comfort indices [6].

The purpose of this study is to calculate and analyze the Outdoor Thermal Comfort Index (OTCI) based on weather / climate conditions over a long period of time at the Mandeh tourism destination location so that a description of the OCTI characteristics in that location will be obtained, in the form of information applications tourism is expected to be useful for tourists and tourism businesses and local governments in developing tourism by providing information on the level of thermal comfort for tourists and planning infrastructure development in the form of appropriate facilities and infrastructure for tourism

\section{METHODOLOGY \\ 2.1 Research Sites}

Tourism, especially natural tourism, is one source of income for development in West Sumatra Province. One of the leading natural tourist destinations in West Sumatra is Mandeh. Administratively, Mandeh is located in Koto XI Tarusan Subdistrict, Pesisir Selatan Regency which consists of 7 villages and 3 villages. Mandeh, Biak and Bunaken have been designated as the main destination for marine tourism sector policies in the National Tourism Development Master Plan (RIPPNAS) by the Indonesian National Development Planning Agency (BAPPENAS) in 2014. Research location as shown in Figure 1.

\subsection{Data}

OCTI is obtained by using climate data input, in the form of air temperature, humidity, wind speed, solar radiation and cloud cover. The climate data used is ERA-Interim reanalysis data sourced from the European Center for Medium-Range Weather Forecasts (ECMWF) because there is no in-situ climate observation in the research location.

Data can be accessed on the website address: https://apps.ecmwf.int/datasets/data/interim-fulldaily/levtype $=\mathrm{sfc} /$. As a comparison, climate observation data is used closest to the research location, namely the Teluk Bayur Meteorological Maritime Station, the data of which can be accessed on the website page: dataonline.bmkg.go.id/data-iklim. The ECMWF ERA-Interim reanalysis data used in this study is in the form of a grid data with a sapasial resolution of $0.125^{\circ} \times 0.125^{\circ}$, with observations selected four times a day, namely 00, 06, 12 and 18 UTC. To represent the Mandeh area data, in this study one location point is in the Mandeh bay, with coordinates $1.195597^{\circ}$ South and $100.429106^{\circ}$ East. GrADS software is used to extract grid data at these locations.

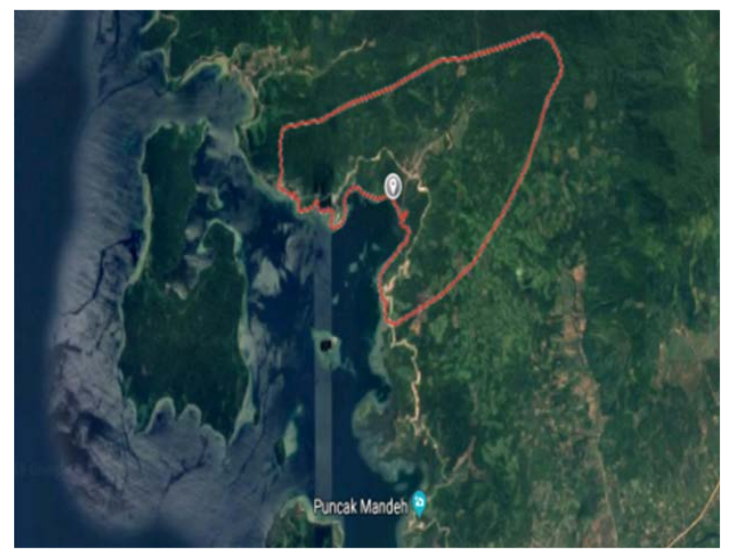

Fig. 1 Location of Mandeh tourism area, and research location (Map source: Google Maps, 2019)

\subsection{Data Processing}

PET will be calculate with the RayMan Pro software version 2.1 was developed to determine the thermal comfort index in simple and complex environmental conditions based on climate data (air temperature, humidity, wind speed and mathari radiation) and thermo physiological data (clothes worn and activities carried out human). $[7,8]$. In this paper, only climate data are considered as variable variables as input data into RayMan Pro software, while thermo physiological data are considered to be constant. The results of RayMan Pro's output consisted of OCTI data in tabular format, with PET criteria and thermal perception as shown in Table 1. To create a visual tamplan used by winsurfer and excel. RayMan Pro software can be obtained at https://www.urbanclimate.net/rayman/

Figure 3a is the frequency distribution of PET index and $3 \mathrm{~b}$. is the frequency distribution of average surface air temperature (T2m) at the study site. In figure 3a can be seen, the maximum daily PET index value every month for a year occurs at 


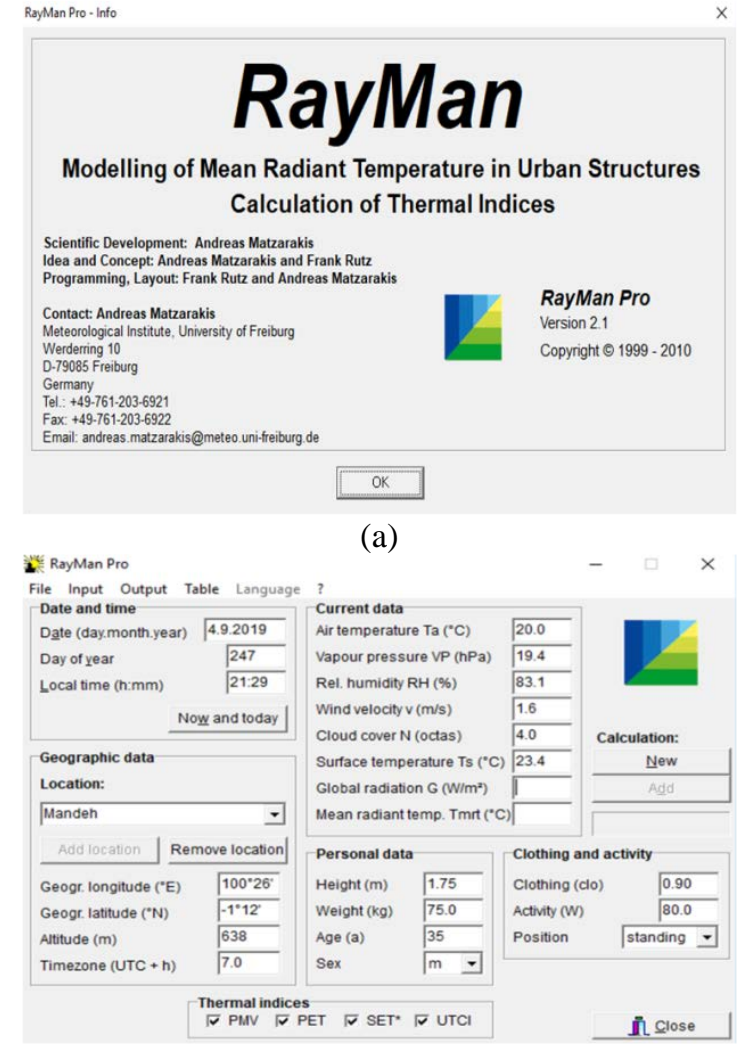

(b)

Fig. 2 Initial appearance of RayMan Pro Version 2.1 software (a) Display of climatic and nonclimatic location settings and parameters for calculating TKT in RayMan Pro Version 2.1 (b) [7].

Table 1 Ranges of the Physiologically Equivalent Temperature (PET) for different grades of thermal perception by human beings and physiological stress on human beings [6].

\begin{tabular}{ccc}
\hline $\begin{array}{c}\text { PET } \\
\left({ }^{\mathrm{O}} \mathrm{C}\right)\end{array}$ & $\begin{array}{c}\text { Thermal } \\
\text { Perception }\end{array}$ & $\begin{array}{c}\text { Grade of } \\
\text { Physiological Stress }\end{array}$ \\
\hline 4 & Very cold & Extreme cold stress \\
8 & Cold & Strong cold stress \\
13 & Cool & Moderate cold stress \\
18 & Slightly cool & Slight cold stress \\
23 & Comfortable & No thermal stress \\
29 & Slightly warm & Slight heat stress \\
35 & Warm & Moderate heat stress \\
41 & Hot & Strong heat stress \\
\hline
\end{tabular}

\section{RESULTS}

3.1 Characteristics of OCTI Mandeh

3.1.1 Mandeh PET frequency

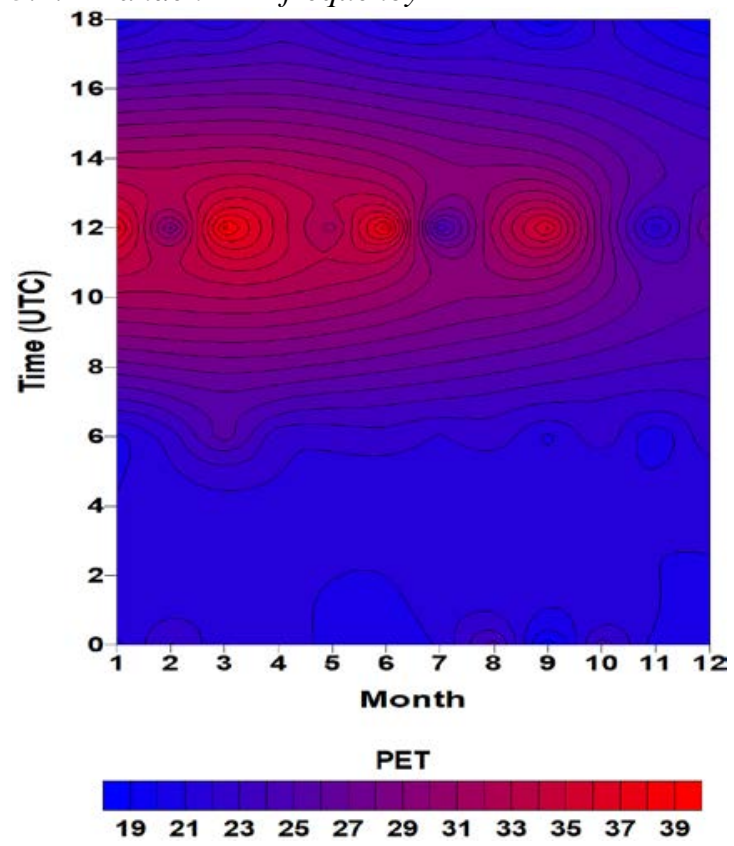

(a)

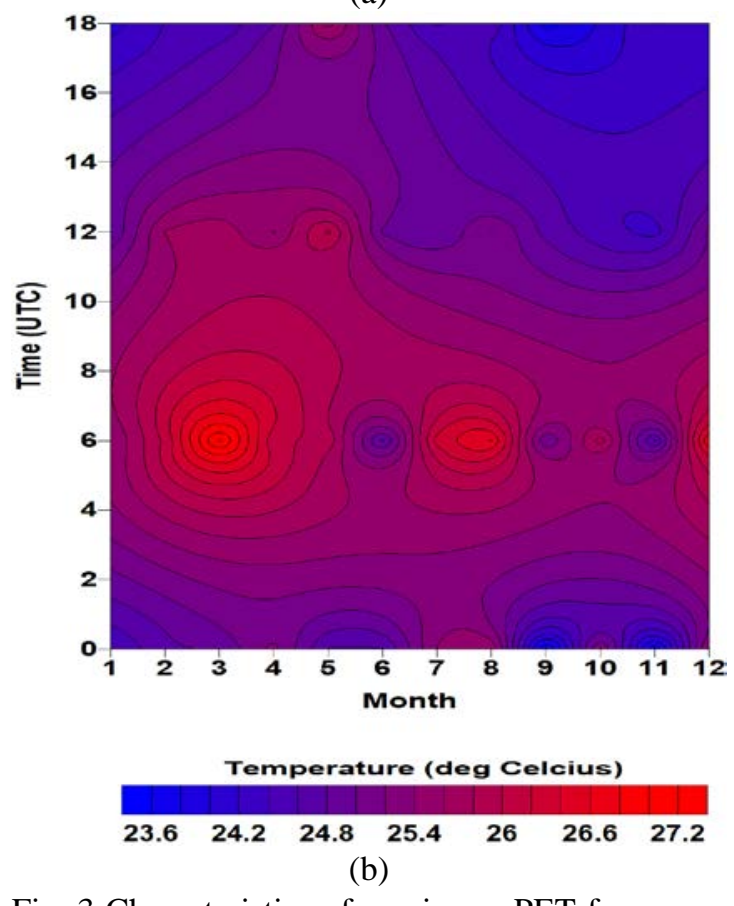

Fig. 3 Characteristics of maximum PET frequency in Mandeh (a) and average surface air temperature in Mandeh (b)

12 UTC. While in Figure 3b shows that the frequency of $\mathrm{T} 2 \mathrm{~m}$ where the highest temperature distribution of T2m occurs more at 06 UTC. Both pictures show that $\mathrm{T} 2 \mathrm{~m}$ does not directly affect the PET index value, meaning there are climate factors other than the T2m factor which also affects the 
PET index value. The allegation that arises is that, given the location of the research in a bay (see Figure 1), causing climate factors that play a role in the formation of the PET index value accumulates at 12 UTC and not 06 UTC. This is also reinforced from the results of the climate element ploting that is used does not indicate the occurrence of peak values of these elements at 12 UTC.

3.1.2 Frequency of OCTI perception in Mandeh

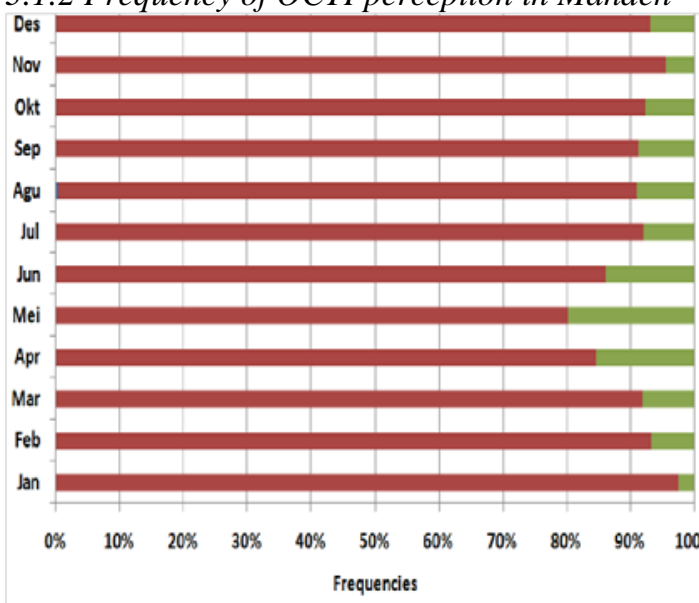

| SlightlyCool | Comfortable || SlightlyWarm | Warm ॥ Hot | VeryHot 00 UTC

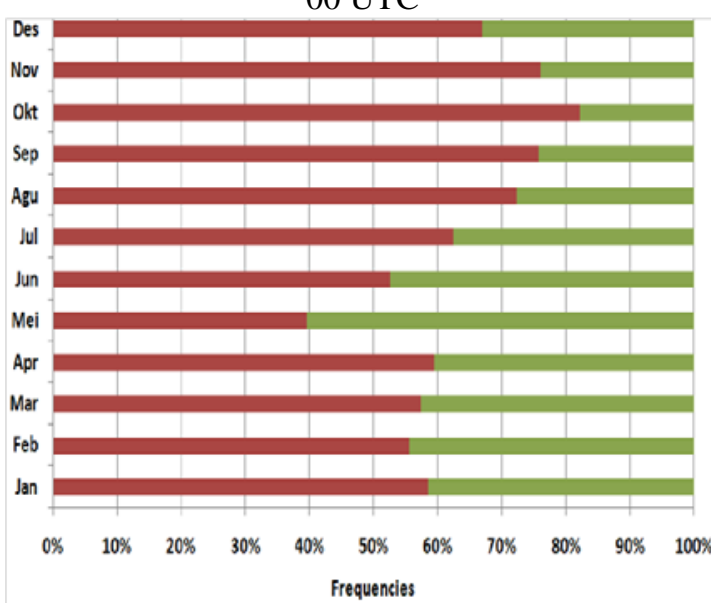

| SlightlyCool | Comfortable \| SlightlyWarm | Warm \| Hot "VeryHot 06 UTC

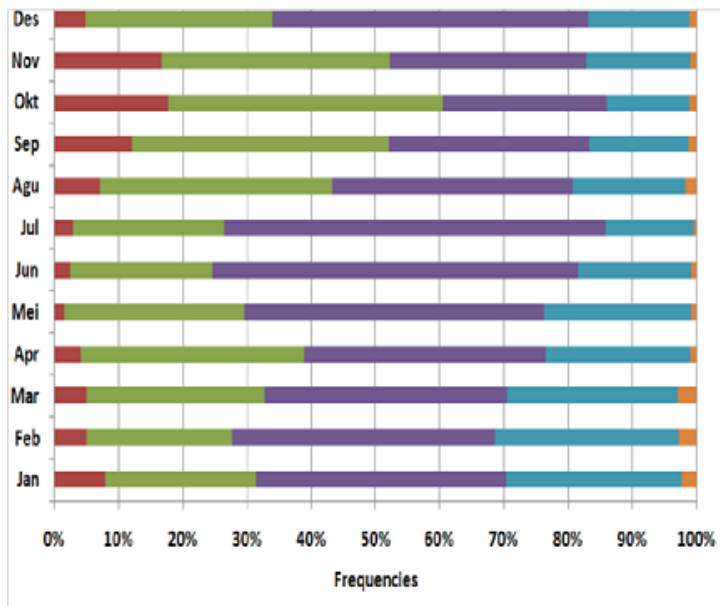

|| SlightlyCool || Comfortable || SlightlyWarm || Warm || Hot | VeryHot

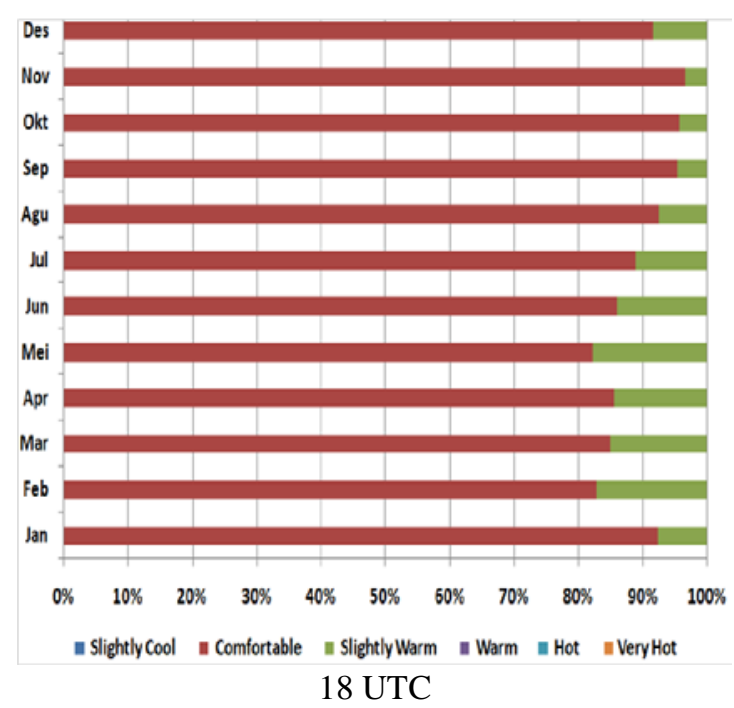

Fig. 4 Frequency distribution of thermal comfort perceptions at 00, 06, 12 and 18 UTC in Mandeh

Figure 4 represents the monthly frequency distribution of OCTI perceptions at 00, 06, 12 and 18 UTC. From the picture it was obtained: at 00 UTC, there were two thermal perceptions that emerged at the study site, namely the OCTI perception of the Comfortable and Slightly warm categories with a percentage reaching around $90 \%$ for the OCTI perception of the Comfortable category and the remaining $10 \%$ for the Slightly warm category. At 06 UTC, the OCTI perception category that appears is the same as what happened at 00 UTC, but with a different percentage level, where at 06 UTC, the appearance of OCTI perception in the Comfortable category on an annual basis is almost the same as, the appearance of OCTI's perception Slightly warm category even in May, the percentage of appearance of OCTI perception in the Comfortable category (40\%) is smaller than the percentage of appearance of OCTI perception in the Slightly warm category (60\%). At 12 UTC, there are 5 categories of OCTI perceptions that appear: Comfortable (7\%), Slightly Warm (31\%), Warm (41\%), Hot (20\%), and Very Hot (1\%) with different percentages for each month that are dominated by OCTI perception categories: Slightly warm, Warm and Hot. OCTI's perception of the Very Hot category with the highest percentage of appearances was in March, February and January, with a process of less than 5\% for each month. At 12 UTC, OCTI's perception of the Comfortable category has very few percentages of occurrence, in this category the most occurred in October (18\%), November (16\%) and September (12\%) while in other months less than $10 \%$, even in May, OCTI's perception of the Comfortable category only appeared around $2 \%$. Furthermore, for 18 UTC, the OCTI perception frequency distribution at this time has a pattern 
that is almost the same as the OCTI perception frequency distribution pattern at 00 UTC.

\subsection{OCTI Trend in Mandeh}

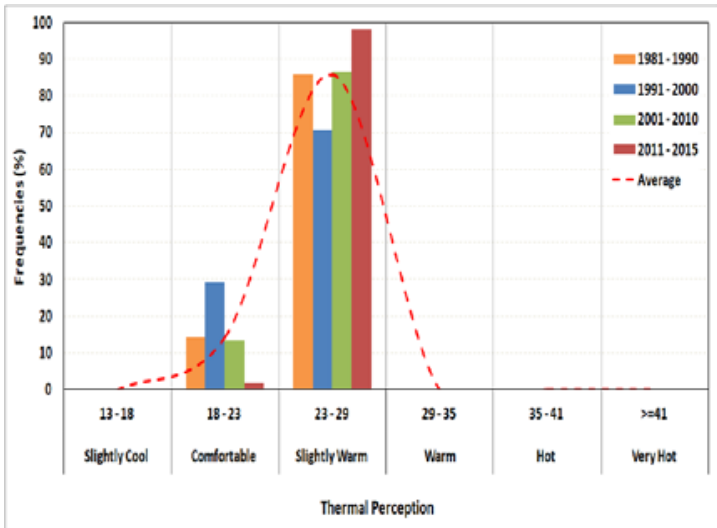

(a)

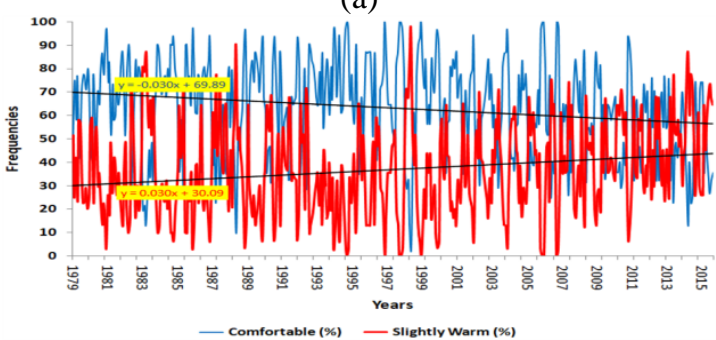

(b)

Fig. 5 Pattern of OCTI perception frequency in Mandeh per decade and (a) OCTI perception trends like the average annual OCTI perception in Mandeh for the Comfortable and Slightly Warm categories (b)

Figure 5a. is a pattern of perceptions of OCTI per ten years (except for the period 2011-2015 only averaged over five years), and Figure $5 \mathrm{~b}$ is an annual average trend for OCTI perceptions in the Comfortable and Slightly Warm categories. In Figure 5a it can be seen that on average ten years there are only two categories of OCTI perceptions in Mandeh, namely the Comfortable and Slightly Warm categories and between the two categories, the Slightly Warm perception category is very dominant. When viewed per-ten years, the 19912000 period is the period with the highest OCTI perception of the Comfortable category (30\%) and the Slightly Warm category at the least (70\%) compared to other ten-year periods. The reverse frequency occurred in the period 2011-2015, where the perception of OCTI in the Comfortable category was the least (2\%) and the Slightly Warm category the most (98\%) compared to other tenyear periods. In line with what has been described in Figure 5a, then the trend of the two dominant perception categories will look like in Figure 5b where, the OCTI perception trend in the Comfortable category tends to decrease while the
OCTI perception trend in the Slightly Warm category tends to increase throughout the data year period 1979-2015.

\section{DISCUSSION}

Climate and tourism are closely related, because climate is one of the very determining factors in the choice of destination and type of travel for trips. The phenomenon of global warming which results in climate change is one of the evidences that is very clearly felt is the increase in global air temperatures. The increase in air temperature in general will also increase the heat stress on the human body so that it will reduce the level of thermal comfort will be more common in the future.

The results of research on climate, climate change and tourism in regions with four seasons, such as the Black Forest tourist area, Germany show that the perception of OCTI in general in the fall will be more comfortable, while spring will be slightly cooler. Conversely, the summer will become warmer and drier, and extreme temperatures are more common. So that during the summer will tend to reduce outdoor activity and delay vacation planning, especially for tourist destinations in the lowlands [9]

The results of Nugroho's research which made a simulation of OCTI adaptation due to global climate change in the city of Padang showed that climate change will cause shifting PET values to be higher and reduce the level of thermal comfort, namely from the OCTI perception of the category Comfortable-Slightly Warm to Slightly WarmWarm . The most suitable adaptation simulation to keep OCTI in the Comfortable category is to provide wind and shade so that the Trm value is lower [10].

Previous research conducted in the cities of Padang and Pekanbaru also showed that the level of OCTI perception was dominated by the Slightly Warm categorization. In Padang City which can be categorized as a seaside city, OCTI's perception of the rather warm category is more common than Pekanbaru City which is located more in the mainland region of Sumatra, and it can be assumed that the OCTI perception of the Comfortable category will also occur more frequently in Pekanbaru City [11].

There are different perceptions of OCTI for tourists in coastal areas and outdoor urban areas, such as city parks or squares. In coastal areas, tourists are more likely to prefer thermal conditions that tend to be warm, while in urban open spaces tourists tend to prefer if the conditions outside the room in conditions that tend to be cool. This is inseparable from the culture that shapes the lifestyle of each tourist [2,3]. 
The tourism business activities offered should also see demographic changes in population. Because demographic changes in population can be used as a basis for consideration to make the type of tourism (health or activity), market segments for customers (family, elderly, or young people), travel time, vacation time and so on. Due to demographic changes in population and increased awareness of climate change and health, it is assumed that tourists will prioritize the type of tourism for health as well as sustainable tourism, in the sense of tourism that does not exploit nature excessively [9].

Based on the results of the processing of climate data that can characterize OCTI in the Mandeh tourist location as described previously, the results can be used as a reference for research and development to become an attractive tourist destination for tourists, friendly to nature and sustainable. Some things that can be developed based on the characteristics of OCTI in the coastal areas such as the development of marine tourism (snorkeling / diving), beach sports, culinary based on marine ingredients can be considered to be developed. The characteristics of the OCTI can also be used as a guideline for the preparation of a visit schedule prepared by tourism businesses in the tour packages that will be offered to tourists, for example in any month you should visit the Mandeh tourist site, at what times you should be outdoors while enjoy the beauty of the beach and so on.

In terms of the sustainability of Mandeh tourism development, the results of the OCTI characterization and some of the discussions above can be used as a reference for not further studies in making Mandeh tourism development policies going forward. The plan, also must consider several things related to the changes that will occur. Climate change, cultural change, lifestyle changes and demographic changes from the community that will be used as a tourism market share. The prospect of selling the value of Mandeh tourism is nature tourism, especially beach tourism which offers more tourist attraction for tourists who are active outdoors (beach).

OCTI's perception needs to be done in field validation as well as capturing the aspirations of tourists and tourism businesses in a series of research processes for making OCTI information applications for Mandeh tourism. This OCTI information application is expected to be a guide for tourists to find out when they will travel so they get the desired comfort. For tourism businesses, information is very important in offering tourism packages to customers. For local governments, information will be very useful in making policies and planning infrastructure development at the Mandeh tourist destination.

\section{CONCLUSION}

From the results of data processing and discussion that have been presented, several conclusions can be obtained, including that OCTI has unique characteristics at each location, depending on the PET value derived from local climate characteristics. These local characteristics must be raised by tourism businesses and local governments to have a sale value for tourists. Characteristics of OCTI Mandeh which is more dominant illustrates the characteristics of OCTI coastal areas should also be an opportunity for tourism businesses and local governments to jointly design and develop them into tourist destinations that are attractive to tourists, friendly to nature and sustainable. To further this characteristic of OCTI Mandeh can be a tourism information application that is widespread and easily accessible to all walks of life that will be traveling.

\section{ACKNOWLEDGMENTS}

This paper is part of the research funded by PNBP UNP for that the authors would like to thank LP2M UNP. The author also thanks the reviewer who corrected this paper for the better.

\section{REFERENCES}

[1] Matzarakis A., C. R. de Freitas and D. Scott. 2004. Advances in Tourism Climatology. Ber. Meteor. Inst. Univ. Freiburg No. 12, 2004, 259 p. ISSN: 1435-618X.

[2] Rutty M. and D. Scott. 2014. Bioclimatic comfort and the thermal perceptions and preferences of beach tourists. Int $J$ Biometeorol 59(1), 37-45, doi: 10.1007/s00484-014-0820-X

[3] Thorsson, S., T. Honjo, F. Lindberg, I. Eliasson and En-Mi Lim. 2007. Thermal comfort and outdoor activity in Japanese urban public places. Environment and Behavior, 39(5): 660-684. doi: 10.1177/0013916506294937

[4] Sangkertadi. 1998. Simulasi kenyamanan thermal untuk lingkungan ber-iklim tropis lembab. Dimensi Arsitektur, 26:35-40.

[5] Sugini. 2004. Pemaknaan istilah-istilah kualitas kenyamanan thermal ruang dalam kaitan dengan variabel iklim ruang. Logika, 1(2). ISSN: 140-2315.

[6] Matzarakis A., Mayer $\mathrm{H}$ dan Iziomon MG. 1999. Application of a universal thermal index: physiological equivalent temperature. Int J Biometeorol 43:76-84. 
[7] Matzarakis A, Rutz F dan Mayer H. 2007. Modelling radiation fluxes in simple and complex environments - application of the RayMan model. Int J Biometeorol 52:323-334

[8] Matzarakis, A. 2009. Additional features of the RayMan model. The seventh International Conference on Urban Climate. Yokohama 29 Juni - 3 Juli.

[9] Endler C. and A. Matzarakis. 2011. Climate and tourism in the Black Forest during the warm season. Int J Biometeorol 55:173-186, doi: 10.1007/s00484-010-0323-3
[10] Nugroho, S. 2011. Kajian simulasi adaptasi terhadap tingkat kenyamanan thermal akibat perubahan iklim global di Kota Padang. Widyariset, 14(3):549-557

[11] Nugroho, S., R. Wilis, Susilowati, dan W. Budilestari. 2011. Tingkat kenyamanan termal di Kota Padang dan Pekanbaru periode data tahun 1982-2002. Megasains 2(4): 240 - 252, ISSN: 2086-5589.

Copyright (C) Int. J. of GEOMATE. All rights reserved, including the making of copies unless permission is obtained from the copyright proprietors. 